\title{
CHRISTELIKE HOËR ONDERWYS EN DIE REGSWETENSKAPPE.
}

Dat ook die regswetenskappe dringend behoefte het aan beligting van uit die grondbeginsels van die Christelike Hoër Onderwys en Wetenskap, is sonder meer daaruit duidelik dat die reg die ganse menslike samelewing, altans wat betref die uitwendige gedraginge daarin, deur vergelding reël. Dit het dus ' $n$ ingrypende uitwerking op die inrigting en ontwikkeling van daardie samelewing in al sy vorme en leringe, ja inderdaad op almal, want elke samelewingskring het sy eie regsreëling wat bepaal watter gevolge van geregtiging, magtiging en verpligting voortvloei uit die wisselende verhoudinge, gedraginge, gebeurtenisse en toestande in daardie kring. Dit geld vir elke gesin en vereniging en maatskappy, maar dit geld ook vir volk, staat en kerk.

Dat die wetenskap van die reg uit Christelike beginsel benader moet word, is van des te meer belang ondat die reg nie alleen gedurig verander 
en ontwikkel nie, maar omdat daardie verandering en ontwikkeling langs normatiewe weg plaasvind, d.w.s. nie alleen so dat dit 'n reël bevat nie, maar ook so dat dit gevorm word volgens 'n reel of ideaal. Die reg is 'n menslike skepping, dit word neergelê deur sosiale organe, en hierdie regsvorming is nie blind of bloot spontaan nie, maar dit is ' $n$ uitvloeisel van meer of minder bewuste beginsels.

Uit die kennis van die regsbeginsels kan die reg dus nie alleen begryp word nie, maar ook prakties beinvloed word. Want hierdie beginsels is wel nie willekeurig nie, ondat hulle ingebed is in die natuur van menslik a samelewing in sy verskillende vorme, maar die insig in hierdie beginsels wissel met die lewensbeskouing en is in die Christelike Hoër Onderwys georiënteer aan die heilige Skrif en, in ons geval, verder aan die Calvinistiese Skrifuitieg en -toepassing.

Hierdie stand van sake is van besondere betekenis nou dat saam met die staatsinrigting ook die gangbare regsreëlinge in die wêreld in die maalstroom of smeltkroes is, altans in 'n oorgang van die ouer meer individualistiese toestand tot 'n nuwe meer solidaristiese toestand. Die gemeenskap van volk en staat en stand en gesin kom op die voorgrond in die regsorde in plaas van die individu en die maatskappy. En in hierdie oorgang is daar gevaar vir verlies van alle vastigheid of eensydige deurdrywing of van die oue of van die nuwe, tensy 'n vaste rigsnoer aangelê word soos deur die Calvinisme in sy Skriftuurlike grondbeginsels gebied, beginsels wat by alle vatbaarheid vir ontwikkeling 'n grondvastigheid het en behou in die rotsbodem van die Godsopenbaring nieteenstaande die wisseling en beroering van are tye.

Deur aan hierdie grondslag vas te hou kan veral ook die gevaar ontwyk word wat nou weer besonder dreigend is, die gevaar naamlik van mensvergoding ook in die regsorde, wat alleen kan lei tot gaos of ondraaglike tirannie. Die gemeenskaplike onderwerping aan God in Christus alleen kan verseker dat sowel individu as gemeenskap, maatskappy en volk, kerk en staat hul eie plek volstaan in onderlinge korrelasie en dat daar in dic volkewêreld naas die nasionale vryheid en selfstandigheid ook verseker sal wees die onderlinge orde en saamwerking.

Die taak van die Christelike Hoër Onderwys in hierdie verband word in Suid-Afrika egter bemoeilik deur die feit dat sowel ons regspraktyk as ons regswetenskap en regsonderwys nominaal losgemaak is van alle beginselinsig en inderdaad beheers word deur die formalistiese positivisme, d.w.s. die opvatting dat die reg willekeurig neergelê word deur die staat en die staat alleen, en dat daarby die inhoud nie bepaal word deur materiële beginsels nie, maar bloot deur die vorm van die staat se regskep- 
pende wilsbesluit hetsy deur wetgewing of deur regspraak. Slegs word hierby tot 'n mate erken die werking van 'n nasionale historiese tradisie en van die moderne sosiale behoefte.

Die gevolg is dat eensdeels slegs die staatlike reg bestudeer word. en wel die van die moderne Suid-Afrika met verwysing na sy historiese antesedente, en andersyds dat klakkeloos geanaliseer en gesistematiseer word wat die howe en die wetgewers belief neer te lê, slegs met 'n geringe mate van historiese kritiek en 'n nog geringer mate van materiële regspolitiek. Die bietjie regsfilosofie wat nog daarby beoefen word, is van die mees oppervlakkige positivistiese stempel. Inderdaad ons regslewe in Suid-Afrika verkeer nog in die stadium van die bare advokatery.

Gevolglik staan ons regswetenskap ook magteloos teen die nuwe gees van volks- of staatsabsolutisme wat hom verset teen die heersende individualistiese en kapitalistiese regsorde en dit rewolusionêr wil vervang deur ' $n$ regsorde gebaseer op die skynbaar materiële beginsel van die volks- of die klasbelang, wat egter ook maar weer neerkom op 'n formalistiese sanksionering van die staatswil, maar nou van 'n nasionaalof sosiaal-diktatoriale staatswil in plaas van die ou demo-liberale.

Ek sê dat ons regswetenskap hierteenoor magteloos staan omdat dit geen prinsipiële verweer of korreksie hierteen het nie, aangesien volgens sy eie beginsel reg is wat die staat bepaal, waruit volg dat as een van die opkomende magte, noem hulle maar nasionaal-sosialisme en kommunisme, die staat in beslag neem, sy nuwe orde soos deur die staat dan bepaal weer reg sal wees, al verskil dit hemelsbreed van die geldende reg.

Dit is dus hoog tyd dat ons regswetenskap en regsonderwys deurdring tot die grondslae van die reg, tot die wêreld van die regsbeginsels, om daarin 'n waarlik materiële. d.w.s. inhoudbepalende, maatstaf vir die regsontwikkeling te vind, ' $n$ maatstaf wat soos gesê aan elke sosiale faktor sy toekomende plek sal aanwys op grond van die Skepperswil, die natuurlike staat van sake en die histories-nasionale en -sosiale ontwikkelingstadium.

I Im hierin die weg te wys is die besondere taak van die Christelike Hoër Underwys, omdat dit terdeë rekening hou met die genoemde faktort en ook voortbou op die grondslae van ons eie nasionale ontwikkeling, wat wesenlik Calvinisties is.

Vie rigting wat daarby ingeslaan moet word, wys baie duidelik op 'n vers.erking van die nasionale en sosiale faktore in die reg, maar met vernyding van alle absolutisme ook in hierdie nuwe ontwikkeling. Wat min of meer die strekking en draagwydte hiervan sal wees, het ek probeer 
aandui in my werkies in die Verkennerreeks (Pro Ecclesia-Drukkery, Stellenbosch), nl. Die Moderne Staat, wat reeds verskyn het, en Algemene Regsleer of Jurisprudensie, wat hopelik binnekort die lig sal sien. Die hoofsaak is dat die regsorde 'n meer organies-korporatiewe karakter moet ontwikkel, sowel internasionaal as nasionaal en sosiaal. wat veronderstel 'n groter mate van eenheidsleiding op aldrie die genoemde gebiede verbonde met onderlinge korrelasie, en die natuurlike ordening van volkegroepe en volkstate met volksreg en volkstande.

Die ontwikkeling van hierdie ideë, wat reeds bemoeilik is deur die genoemde agterstand van ons Suid-Afrikaanse regswetenskap, word verder belemmer deur die skaarste van beskikbare kragte en die huidige verwarring, onenigheid en verslapping in ons nasionale leiersgeledere.

Ons eie universitêre inrigting is deur hierdie euwels en veral die eerste ook aangetas, sodat nie te veel van ons verwag moet word en meer besonder in die naaste toekoms nie. Maar daar kan geen twyfel aan wees nie dat die gesonde beginsels van Christelike Hoër Onderwys soos deur ons en ander bewuste Calviniste en goedgesinde Christene van ander nasionale skakeringe weer in die lig gestel en bekend gemaak, sal deurwerk en die jeugdige kragte van die opkomende Christelik-Nasionale geestelike leierskorps sal inspireer en lei tot volvoering van die taak wat hierbo slegs in floue omtrekke aangedui is. Dat dit sal gebeur, is 'n Christelike en nasionale lewensbelang. Daarom hoop ons nie alleen daarop nie, maar sien ons daarna uit met 'n vasversekerde geloof wat deur geen krakeel vernietig kan word nie. 